\title{
Adenomatoid Odontogenic Tumour - Case Series
}

\author{
V S Kumar Bhagavathula ${ }^{1 *}$, Dr. R V Kishore Kumar², Dr. Sridhar Reddy Kanubaddy ${ }^{3}$
}

${ }^{1}$ Post Graduate, Department of Oral and Maxillofacial Surgery, Narayana Dental College and Hospital, Nellore, Andhra Pradesh - 524003, India ${ }^{2}$ MDS, Professor, Department of Oral and Maxillofacial Surgery, Narayana Dental College and Hospital, Nellore, Andhra Pradesh - 524003, India ${ }^{3}$ MDS, Associate Professor, Narayana Dental Coleege and Hospital, Nellore, Andhra Pradesh - 524003, India

\begin{tabular}{|c|c|}
\hline DOI: $10.36347 /$ sjds.2021.v08i04.002 & | Received: 16.03.2021 | Accepted: 19.04.2021 | Published: 24.04.2021 \\
\hline \multicolumn{2}{|c|}{ *Corresponding author: V S Kumar Bhagavathula } \\
\hline Abstract & Original Research Article \\
\hline \multicolumn{2}{|c|}{$\begin{array}{l}\text { Adenomatoid odontogenic tumor (AOT) was first described by Steinmann in } 1905 \text {. It is a relatively rare benign } \\
\text { odontogenic tumour accounting for } 3 \% \text { of all odontogenic tumours [1]. Philpsen coined the term - Adenomatoid } \\
\text { odontogenic tumour. It has distinct clinicopathological appearance but often misdiagnosed as cyst. In this paper, we } \\
\text { present a case series of } 16 \text { cases in different locations of maxilla and mandible. } \\
\text { Keywords: Adenomatoid odontogenic tumor (AOT), clinicopathological appearance, maxilla and mandible. }\end{array}$} \\
\hline $\begin{array}{l}\text { Copyright } \odot 2021 \text { The Author(s): This is } \\
\text { icense (CC BY-NC 4.0) which permits u } \\
\text { uthor and source are credited. }\end{array}$ & $\begin{array}{l}\text { ributed under the terms of the Creative Commons Attribution } 4.0 \text { International } \\
\text {, and reproduction in any medium for non-commercial use provided the original }\end{array}$ \\
\hline
\end{tabular}

\section{INTRODUCTION}

AOT, is a relatively rare benign tumour originating from odontogenic epithelium, accounting for $3 \%$ of all odontogenic tumours ${ }^{1}$. Steinmann in 1905 was the first to describe AOT as slow growing, benign odontogenic neoplasm. Later, in 1959, Philpsen and Brin coined the term Adenomatoid odontogenic tumour, were later adopted by the World Health Organisation and classified it as odontogenic tumor I 1971. AOT has definite female predilection (2:1), with age distribution ranging between 13-19 yrs with maxilla being almost twice as likely as the mandible. Most commonly, in anterior maxilla, AOT is associated with impacted canines (60\% cases) [2]. It is also noted in the literature that AOT can also occur in posterior maxilla and mandible distal to premolar region (9\% cases). AOT has 3 clinical presentation - Intra osseous (follicular) most common variant $-70 \%$ of cases - in association with impacted tooth; Intra osseous - extrafollicular $25 \%$ of cases and the extra osseous variant - relatively rare accounting for $5 \%$ of cases. In general, AOT cases are mild expansile in nature with sizes varying from 1$3 \mathrm{cms}$ in diameter. Radiographically, AOT cases usually present as well - defined to corticated unilocular radiolucent lesion. Rarely, $10 \%$ of cases demonstrate calcifications. On histopathological examination, AOT has epithelial strands of spindle shaped cells, epithelial spheres/ whorls and cuboidal cells arranged in duct like structure with or without calcifications. The characteristics features of AOT is that the tumour is supported by a thick, fibrous connective tissue capsule which makes the delineation of tissue capsule from the tooth and surrounding bone easy.

The treatment of choice is conservative surgical approach i.e, curettage, enucleation or combination. The choice of surgical approach depends on - age of the patient, tooth involved, stage of tooth development, whether to retain or remove. Recurrence is exceedingly rare in these tumors, although noted as per review of literature.

\section{MATERIALS AND METHODS}

This is a retrospective study in which 16 cases were retrieved from Dept. of Oral and Maxillofacial Surgery and Dept, of Oral Pathology in Narayana Dental College and Hospital, Nellore. The clinical photographs and radiographic findings were reviewed. Also H\&E stained glass slides were reviewed by an oral pathologist to confirm the diagnosis of AOT.

\section{Case Report -1}

A 13 year old male patient, reported to the department of oral and maxillofacial surgery with a complaint of swelling in left side of face since 1 year. The patient attenders revealed that initially the swelling was small in size and gradually it increased in size to reach its present size in 3 months duration. Also, patient gives history that the mass was neither associated pain, discharge nor history of trauma. No history of systemic diseases.

On examination, mild facial asymmetry noted in relation to left side of face. On palpation of $3 \times 2 \mathrm{~cm}$ 
in size and was firm in nature. On intra oral examination, solitary swelling obliterating nasolabial fold with well define demarcation, extending from 22 to 25 region; with roughly oval shape. There was obvious vestibular space obliteration. On dental examination, missing 23, 24 noted with retained 63 . On palpation, swelling was firm in consistency and nontender. Egg shell cracking noted indicating resorption of anterior wall of maxilla. Palatally, there was no swelling and palatal mucosa is firm and normal. Provisionally, the lesion was diagnosed as odontogenic tumour.
Radiographic finding revealed well defined radiolucent lesion in left maxillary region with impacted 23 (with incomplete root formation) and 24 with completed root formation. Resorption of root noted irt retained 63; displacement of 25 noted. Enucleation was done along with impacted 23, 24. On 3 months follow up, patient was apparently normal. Histopathology report confirmed AOT.

\section{Case 1}
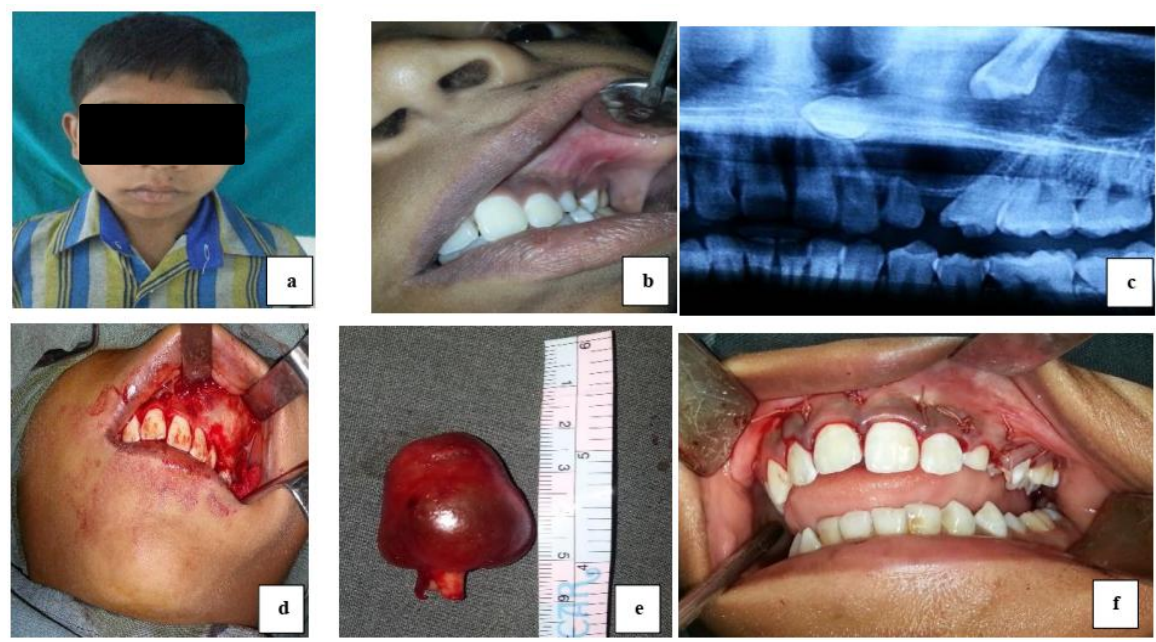

Fig-1: (a-c) Pre operative photographs, (d-f) intra op photographs

\section{Case Report - 2}

A $11 \mathrm{yr}$ old female patient reported with chief complaint of painless, slow growing swelling in lower anterior jaw region since 6 months. Patient was asymptomatic 6 months ago and swelling gradually increased and attained present size. Patient denies history of trauma, discharge or pain in the region of swelling. On examination, there was mild facial asymmetry with an obvious enlargement of the lower one third of the face. Swelling was roughly oval in shape measuring $4 \times 5 \mathrm{~cm}$ approximately. Intraorally a well defined nodular, alveolar enlargement was noticed extending from 41 to 45 region, inferiorly extending to the depth of the vestibule. The gingival over the swelling was normal but stretched. On dental examination, there was retained 83 and missing 43. The teeth involved in the lesion were mobile and severely displaced. There was an obvious bicortical expansion involving both buccal and lingual cortices. On palpation,the lesion was firm in consistency with areas of perforation on the buccal cortex. Lingual cortex was intact. Radiographically, OPG revealed a well defined circumscribed radiolucency with a sharp sclerotic border. A differential diagnosis of radicular cyst, ameloblastoma, dentigerous cyst and AOT were considered and surgical enucleation was planned under general anesthesia. A crevicular incision was placed from 33 to 44 . Healthy and sound bone was identified and mucoperiosteal flap was raised off the lesion on the buccal aspect. The buccal cortex was almost thinned off leaving only wafer thin bone covering the mass. This thinned out bone was nibbled and removed all along the mass. The mass was easily separable from the lingual cortex and was enucleated intoto along with the associated teeth. The bed of the cavity was examined for any remnants of the lesion. Hemostasis achieved. Mucoperiosteal flap closure done. The bony defect healed well in post op follow up of 6 months. The patient was then referred to department of prosthodontics for dental rehabilitation. Histopathology report confirmed the diagnosis of Adenomatoid odontogenic tumor. 
Case 2

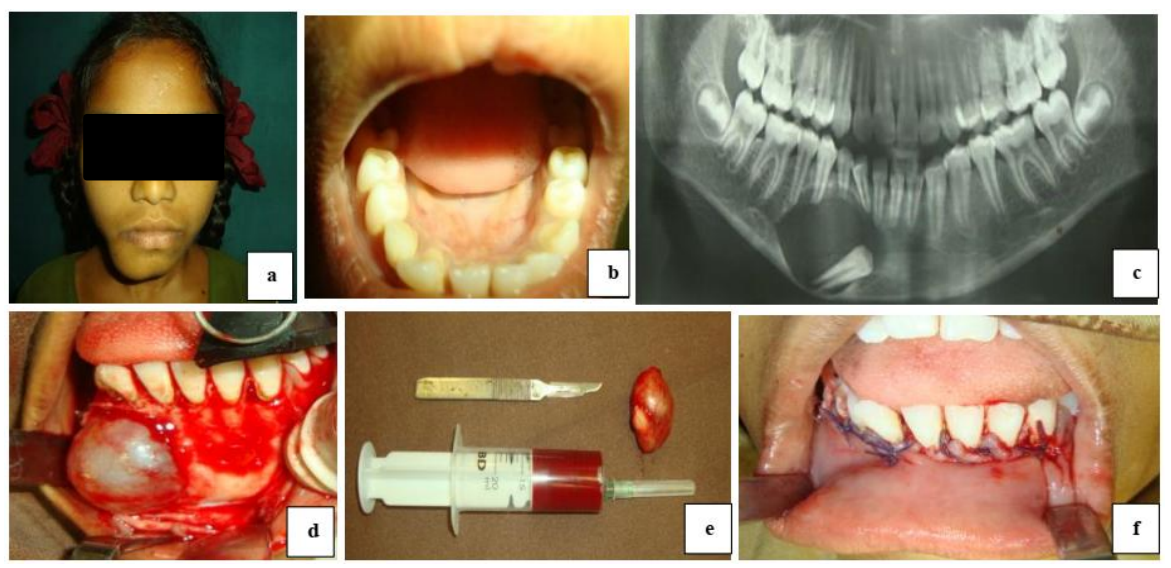

Figure: (a-c) pre operative photographs (d-f) intra op photographs

\section{RESULTS}

Table-1 summarizes the main clinical, radiographic and various treatment modalities executed in a total of 16 cases operated at Narayana Dental College and Hospital, Nellore, Andhra Pradesh.

All the cases were intra bony. Of the 16 cases, 12 were female and 4 were male with an age range of 10-30yrs. Maxilla was most commonly affected in 12 cases $(75 \%)$ and rest were in mandible $(25 \%)$. Out of 16 cases, 9 had impacted canine 6 in maxilla and 3 in the mandible) within the lesion and Majority of the cases had swelling and vestibular space obliteration. Two cases were discussed in detail in this paper - one in the maxilla and the other in the mandible.

Table-1

\begin{tabular}{|c|c|c|c|c|}
\hline CASE & AGE/SEX & SITE & CLINICAL & RADIOGRAPH \\
\hline 1 & $13 / \mathrm{M}$ & $\begin{array}{l}\text { LEFT ANTERIOR } \\
\text { MAXILLA }\end{array}$ & $\begin{array}{l}\text { SWELLING WITH VESTIBULAR } \\
\text { OBLITERATION }\end{array}$ & $\begin{array}{l}\text { UNILOCULAR RADIOLUCENCY WITH } \\
\text { IMPACTED } 23,24 \text {. }\end{array}$ \\
\hline 2 & $30 / \mathrm{F}$ & $\begin{array}{l}\text { LEFT ANTERIOR } \\
\text { MAXILLA }\end{array}$ & SWELLING & $\begin{array}{l}\text { UNILOCULAR RADIOLUCENCY WITH } \\
\text { IMPACTED } 23\end{array}$ \\
\hline 3 & $11 / \mathrm{F}$ & $\begin{array}{l}\text { ANTERIOR } \\
\text { MANDIBLE }\end{array}$ & $\begin{array}{l}\text { SWELLING WITH VESTIBULAR } \\
\text { OBLITERATION }\end{array}$ & $\begin{array}{l}\text { UNILOCULAR RADIOLUCENCY WITH } \\
\text { IMPACTED } 43\end{array}$ \\
\hline 4 & $16 / \mathrm{F}$ & $\begin{array}{l}\text { RIGHT MAXILLA } \\
\text { (IMPACTED 14) }\end{array}$ & SWELLING & $\begin{array}{l}\text { UNILOCULAR RADIOLUCENCY WITH } \\
\text { IMPACTED } 14\end{array}$ \\
\hline 5 & $20 / \mathrm{F}$ & ANTERIOR MAXILLA & SWELLING & $\begin{array}{l}\text { UNILOCULAR RADIOLUCENCY WITH } \\
\text { IMPACTED } 23\end{array}$ \\
\hline 6 & $11 / \mathrm{M}$ & $\begin{array}{l}\text { ANTERIOR } \\
\text { MANDIBLE }\end{array}$ & $\begin{array}{l}\text { SWELLING WITH VESTIBULAR } \\
\text { OBLITERATION }\end{array}$ & $\begin{array}{l}\text { UNILOCULAR RADIOLUCENCY WITH } \\
\text { IMPACTED } 42\end{array}$ \\
\hline 7 & $12 / \mathrm{F}$ & RIGHT MAXILLA & SWELLING & $\begin{array}{l}\text { UNILOCULAR RADIOLUCENCY WITH } \\
\text { IMPACTED } 12\end{array}$ \\
\hline 8 & $9 / \mathrm{F}$ & LEFT MAXILLA & SWELLING & $\begin{array}{l}\text { UNILOCULAR RADIOLUCENCY WITH } \\
\text { IMPACTED } 22,23,24\end{array}$ \\
\hline 9 & $10 / \mathrm{M}$ & RIGHT MAXILLA & $\begin{array}{l}\text { SWELLING WITH VESTIBULAR } \\
\text { OBLITERATION }\end{array}$ & $\begin{array}{l}\text { UNILOCULAR RADIOLUCENCY WITH } \\
\text { IMPACTED } 15\end{array}$ \\
\hline 10 & $14 / \mathrm{M}$ & RIGHT MANDIBLE & SWELLING & $\begin{array}{l}\text { UNILOCULAR RADIOLUCENCY WITH } \\
\text { IMPACTED } 44\end{array}$ \\
\hline 11 & $18 / \mathrm{F}$ & $\begin{array}{l}\text { ANTERIOR } \\
\text { MANDIBLE }\end{array}$ & $\begin{array}{l}\text { SWELLING WITH VESTIBULAR } \\
\text { OBLITERATION }\end{array}$ & $\begin{array}{l}\text { UNILOCULAR RADIOLUCENCY WITH } \\
\text { IMPACTED } 33\end{array}$ \\
\hline 12 & $15 / \mathrm{F}$ & ANTERIOR MAXILLA & SWELLING & $\begin{array}{l}\text { UNILOCULAR RADIOLUCENCY WITH } \\
\text { IMPACTED } 13\end{array}$ \\
\hline 13 & $22 / \mathrm{F}$ & RIGHT MAXILLA & SWELLING & $\begin{array}{l}\text { UNILOCULAR RADIOLUCENCY WITH } \\
\text { IMPACTED } 15\end{array}$ \\
\hline 14 & $20 / \mathrm{F}$ & LEFT MAXILLA & SWELLING & $\begin{array}{l}\text { UNILOCULAR RADIOLUCENCY WITH } \\
\text { IMPACTED } 24\end{array}$ \\
\hline 15 & $26 / \mathrm{F}$ & ANTERIOR MAXILLA & $\begin{array}{l}\text { SWELLING WITH VESTIBULAR } \\
\text { OBLITERATION }\end{array}$ & $\begin{array}{l}\text { UNILOCULAR RADIOLUCENCY WITH } \\
\text { IMPACTED } 13\end{array}$ \\
\hline 16 & $14 / \mathrm{F}$ & ANTERIOR MAXILLA & SWELLING & $\begin{array}{l}\text { UNILOCULAR RADIOLUCENCY WITH } \\
\text { IMPACTED } 23\end{array}$ \\
\hline
\end{tabular}




\section{DISCUSSION}

AOT is relatively uncommon benign odontogenic tumor of comprising of $3 \%$ of all odontogenic tumors $[1,2]$. It has characteristic clinical features that make the diagnosis more obvious. The tumor is largely confined to young adults with $2 / 3$ rds of the cases occurring in the age group between $10-$ $19 y$ yrs. Its occurance in most of the times confined to anterior region with $2 / 3$ rd cases in maxilla. Cases were also noted in mandible and paranasal sinus regions. There is definite predilection for females and always associated with an unerupted tooth, most commonly canine [4]. Marx [6] described it as $2 / 3$ rds tumor due to these characteristic features. In our study we also noted that cases were having predilection for female gender, anterior maxilla with most of the cases having impacted canine.

Philipsen and Reichert [5] have described three clinico-pathological variants namely - follicular, extrafollicular and peripheral. The follicular variety is associated with an impacted tooth where as extrafollicular variety is not associated with an impacted tooth. In our study we noted that all cases were of follicular variant.

Radiographically the lesion may mimic other odontogenic lesions such as dentigerous cysts, globulomaxillarycyst, and odontogenic kertocyst and hence histopathological diagnosis is the ultimate deciding factor for the final diagnosis.

Displacement of teeth involved in the lesion, the characteristic feature of AOT rather than root resorption, was noted in our cases. Peripheral lesions show cortical erosion. Calcifications were noted in $78 \%$ of the AOT cases. Immunohistochemistry features show cytokeratin (CK5, CK17, CK19) positive similar to that seen in follicular cyst $[6,7]$.

\section{CONCLUSION}

This relatively uncommon lesion can be easily mistaken for a dentigerous cyst and hence it must be considered in the differential diagnosis of anterior jaw swellings. Although it is originally classified under benign tumors, the clinical behavior is very much similar to cyst. The recurrence rate is also low with good prognosis and hence conservative management in the form of enucleation should be the gold standard treatment of choice.

\section{REFERENCES}

1. Kundoor VK, Maloth KN, Guguloth NN, Kesidi S. Extrafollicular adenomatoid odontogenic tumor: An unusual case presentation. Journal of Dentistry. 2016 Dec;17(4):370.Ankit chug

2. Vasudevan K, Kumar S, Vijayasamundeeswari SV. Adenomatoid odontogenic tumor, an uncommon tumor. Contemporary clinical dentistry. 2012 $\operatorname{Apr} ; 3(2): 245$.

3. Al-Shimari F, Chandra S, Oda D. Adenomatoidodontogenic tumor: Case series of 14 with wide range of clinical presentation. Journal of clinical and experimental dentistry. 2017 Nov;9(11):e1315.

4. Philipsen HP, Reichart PA. Adenomatoid odontogenic tumour: facts and figures. Oral oncology. 1999 Mar 1;35(2):125-31.

5. Marx RE, Stern D. Oral and maxillofacial pathology: a rationale for diagnosis and treatment. Hanover Park, IL: Quintessence Pub. Co., 2012.

6. Baskaran P, Misra S, Kumar MS, Mithra R. Adenomatoid odontogenic tumor-A report of two cases with histopathology correlation. Journal of clinical imaging science. 2011;1.

7. Sharma N, Passi S, Kumar VV. Adenomatoid odontogenic tumor: As an unusual mandibular manifestation. Contemporary clinical dentistry. 2012 Apr;3(Suppl1):S29. 